\title{
STRATEGIC CHOICE OF TECHNOLOGY TRANSFER IN INDONESIA
}

\author{
Syafrizal Maludin ${ }^{* 1}$, Rizal Syarief ${ }^{* *}$, Amzul Rifin ${ }^{* * *}$, and Nurul Taufiqu Rochman ${ }^{*}$ \\ ${ }^{*}$ Center for Innovation, Indonesian Institute of Sciences \\ Jl. Raya Jakarta-Bogor, Km.47 Cibinong, Bogor 16911 \\ ${ }^{* *}$ School of Business, IPB University \\ Jl. Raya Pajajaran, Bogor 16151 \\ ${ }^{* * *}$ Departement of Agribusiness, Faculty of Economics and Management, IPB University \\ Jl. Kamper, Wing 4 Level 5 Campus of IPB Darmaga Bogor 16680
}

\begin{abstract}
Research shows technology development is one key element of economic growth. The race in innovation technology leads the government to issue policies in order to enhance competitiveness based on innovation technology. This commitment is mostly followed by allocating some amount of budget in science and technology development. On the other side, it should be comprehended that innovation creates its own arteries which encourage the government to create an appropriate strategic choice which meets the expectation based on the unique competence of a nation. This article measures the strategic choice for policy maker in establishing an appropriate technology transfer system based on the opinion of actors that involve in technology transfer utilizing analytical hierarchy process (AHP) that analyzes the individual variables in three hierarchies. The variables were derived from the first discussion with experts as the higher level of decision maker. Additionally, research problems were based on the first process of discussion of AHP with experts enriched by literature study. The choices of strategy in this research include developing technology \& business incubator at 0.50414, establishing science attaché at 0.24344, strengthening existing public research institution at 0.16648 and increasing gross expenditure on research and development at 0.08594 .
\end{abstract}

Keywords: AHP, policy maker, technology transfer, strategic choices

\begin{abstract}
Abstrak: Riset menunjukan peran perkembangan teknologi sebagai salah satu elemen penting dalam pertumbuhan ekonomi. Kompetisi dalam arena inovasi teknologi berpengaruh pada pemerintah untuk mengeluarkan kebijakan dalam penguatan daya saing bangsa berbasis inovasi teknologi. Komitmen ini seringkali diikuti dengan alokasi anggaran untuk kegiatan riset dan teknologi. Namun, penguatan ini harus diikuti dengan pemahaman bahwa inovasi menciptakan alur prosesnya sehingga pemerintah diharapkan mampu menciptakan pilihan strategi yang searah dengan tujuan yang berakar dari nilai lokal. Tulisan ini mengukur pilihan strategi yang dapat digunakan oleh pembuat kebijakan dalam menciptakan alih teknologi yang didasarkan pada visi pakar pada bidang alih teknologi dengan menggunakan pendekatan analytical hierarchy process (AHP) yang terbagi dalam tiga struktur hirarki. Variabel yang digunakan diturunkan dari interview pertama dengan pakar dan pengambil keputusan. Masalah riset pada kajian ini juga diturunkan dari interview dengan pakar yang diperkaya dengan penelaahan literatur. Pilihan strategi pada kajian ini adalah pengembangan inkubator dan taman sains dan teknologi 0,50414, pembukaan attaché iptek 0,24344, penguatan litbang 0,16648 dan peningkatan anggaran riset 0,08594 .
\end{abstract}

Kata kunci: AHP, alih teknologi, pembuat kebijakan, pilihan strategi

\footnotetext{
${ }^{1}$ Corresponding author:

Email: syafrizal_maludin@yahoo.com
} 


\section{INTRODUCTION}

The role of Government in developing technology that leads to utilization in developing countries is significant (Aghion et al. 2009; DJHKI, 2007; OECD, 2007; Rosenberg, 1974; Verspagen, 1996). It is related to the range of downstream to upstream in technology development (Adner and Rahul, 2010; Gambardella and McGahan, 2010; Hasheminejad et al. 2011). In one hand, specialists who work in the laboratories have their own scientific objectives. The problem occurs when the government expects the result of technology application in short run while the researchers have their own world that have difficulties in seeing the business and commercialization as the target. On the other hand, some researchers that work in the upstream level of technology attempt have better knowledge of customer needs. These gaps are perfectly described by Alvin Roth in matching market in the kidney exchange (Roth et al. 2005). The gap between demand of kidney and donor of kidney is similar to demand and supply of technology.

The gap of demand in the kidney-case also occurs in the technology-based product where the offer of new application of technology has not met the demand. The market is not established and the supply of technology has not reached the utilization. While some uncommon cases have occurred in Indonesia, a number of advancetechnologies that have demands and are acknowledge by the potential users fail to reach the end. For example, the development of bio-refinery that successfully utilizes the indigenous-super-microbes that are able to produce ethanol more efficient or wheat and soybean plantations that are able to reach commercial scale. Then, importing those products are the better choice.

Innovation technology makes life healthier and more comfortable; however, technology transfer might lead to an increase of illegal drugs, for example. As it comes in balance, the ability in selecting right application of new technology is essential (Shen et al. 2010). As most researchers claim that better technology of modification of gene can feed people on earth, and they never experience starvation that is caused by unavailability of food. Most starvation is caused by political conflict or lack of education. It breaks one of Malthus principles that compares consumption pattern as arithmetic measurement and population growth pattern as a geometric measurement which leads to a shortage of food (Fiaschi and Signorino, 2003).
Meanwhile, the Global trend of manufacturing industry has been led to Industry 4.0 that best describes as utilization of the cyber-physical system (Davies, 2015; Henning and Kagermann, 2013; Pfeiffer, 2017; Santos et al. 2017). This initiative has been anticipated by both agency and structure in global, regional, national and firm levels. Number of programs are developed under the directive order of Making Indonesia 4.0 that is led by Ministry of Industry of the Republic of Indonesia. There are five programs including Food and Beverages Industry, Textile and Apparel Industry, Automotive Industry, Chemical Industry, and Electronic Industry (Kementerian Perindustrian, 2018). Both pictures reflect significance role of technology transfer in economic growth (Reisman, 2005). It leads to abundant criteria, objectives and strategic choices. It has also been influenced by the dynamic of industrial revolution that is not easy to predict. In 1970s, the projection of future technology was in space and aeronautics but in 20 centuries, most of advance development is in biotechnology. It leads to the forecasting of nuclear technology that would develop significantly after bioeconomy era which turns to be the era of internet of things (IOT) marked by the Industrial 4.0.

Trend in technology development influences the shape of industrial sector. The old blue-chip companies have to give up to the new-big-companies such as Viacom, TimeWarner, Sony, and Comcast of Disney. Therefore, it is admitted that the capability of one nation to pursue better strategy in technology transfer is necessary. This research offers a choice in crafting a design of technology transfer system.

This research utilized the Analytics Hierarchy Process (AHP) as the top-down approach. It describes the existing status of technology transfer system in Indonesia sourced from the group of experts. In the first meeting, the experts described their views on ex-post of technology transfer process and how they described the ideal concept. In the second meeting, the experts were involved in direct interviews to complete the questionmatrix. From the observation, this research addresses problems in technology transfer system by providing choices to craft the design strategy.

Previous articles on technology transfer in Indonesia. It hit 3,341,180 articles of technology transfer by using Google scholar varied by methodology, scale, coverage and sector. In Indonesia, the highest citation for technology transfer is Industrialisasi di Indonesia 
(Industrialization in Indonesia) written by Thee Kian Wie. Other related articles are shown in Table 1. The emphasis of this article is the system of technology transfer in the government funded research organization dominated by evolutionary publications. This research aims to provide choices of strategies in crafting the policy of technology transfer system as the selfevaluation by the group of experts.

\section{METHODS}

The respondents included 5 echelon 1 staff from Ministry of Research Technology and Higher Education (echelon 1), one of echelon 1 from Ministry of Home Affairs of the Republic of Indonesia, three of echelon 3 and 4 in four Government Research Institutes, and Secretary General of association of technology and business incubator. The interviews were conducted in Jakarta.

This research administered ethics which protect the confidentiality of the respondents selected based on the criteria of education, experience and acknowledgement. It was followed by informal communication to give a flash information on the research and the methodology.

The methodology included two interviews with the experts of technology transfer. In the first interview, the respondent had introduced some words of technology transfer taxonomy and decided how the experts see the success of technology transfer in Indonesia. Data collection was conducted in the second round in the form of guided-questionnaire. Each of variable was compared against the objective. We utilized the scoring system for analytical hierarchy process. AHP Scale in Table 2.

It required two meetings with each of respondent. In the first meeting, the respondents were free to explain his/her historical background which include their experience in commercialization of research. In the second meeting, the respondents were interviewed based on the question-matrix of AHP. It was followed by the consistency-test and calculation of geometricmeans prior running the value in Super Decision Software.

Technology transfer is a concept of the movement of know-how, technical knowledge, or technology from one organizational setting to another (Roessner and Wise, 1994). This concept shows the flow of technical knowledge which recognizes the different organizational setting. In this article, the technology transfer process flows from the government-funded research center to another organization type such as industry or community. Industries run their activities and conduct trial-error, and when they face problems, they are supported by research and development division that searches for potential solution from the external source. The research shows rejections from personnel to operate invention from external source, and this is called not invented here syndrome(Agrawal et al. 2010; Burcharth et al. 2014; Grosse Kathoefer and Leker, 2012; Ringel et al. 2017). General obstacles of technology transfer are described in Table 3.

Table 1. Research on technology transfer in Indonesia

\begin{tabular}{ll}
\hline \multicolumn{1}{c}{ Author } & \multicolumn{1}{c}{ Title } \\
\hline Sulastri (2014) & Analisis kewajiban alih teknologi dalam investasi asing di Indonesia \\
Mubarok (2007) & $\begin{array}{l}\text { Alih teknologi melalui perjanjian lisensi kaitannya dengan undang-undang nomor 14 tahun } \\
\text { 2001 tentang paten }\end{array}$ \\
Sugiyono et al. (2008) & $\begin{array}{l}\text { Science and technology network in the innovation system of up-stream palm oil Industry in } \\
\text { Indonesia }\end{array}$ \\
Simamora et al. (2005) & Regional innovation system and sustainable competitiveness: case study on food processing \\
& of MSMEs in West Java and Lampung Provinces \\
Aiman et al. (2004) & National Innovation System of Indonesia: a Journey and Challenges \\
Maludin (2009) & Strategi Pengembangan Produk Inovasi \\
\hline
\end{tabular}


Table 2. AHP Scale

\begin{tabular}{cll}
\hline Intensity & Definition & Description \\
\hline 1 & Equal importance & Both elements contribute equally to objective \\
3 & Moderate importance & Experience and judgment slightly favor one element over another \\
5 & Strong importance & Experience and judgment strongly favor one element over another \\
7 & Very strong importance & Demonstrates very strong element \\
9 & Extreme importance & The evidence favoring one element over another is the highest possible order of \\
& & affirmation \\
\hline
\end{tabular}

Intensity of 2, 4, 6 and 8 can be used to express intermediate values

Source: (Saaty, 2003)

Table 3. Technology Transfer Barrier

\begin{tabular}{lll}
\hline Technical barriers & Regulatory barriers & People barriers \\
\hline Technical risk & Lack of technical orders for the users & Unawareness of new technology \\
Lack of a defined requirement & Lack of regulations defining the use of & Lack of communication \\
Equivocality & the technology & Lack of information \\
Lack of operational test data & Long development and procurement lead & Technology push versus market pull \\
Risk Aversion & times & Lack of transfer experience \\
& Changing specifications & Lack of motivation \\
& & Distance (geographical and cultural) \\
& & Too busy \\
& & Unimportant job function (transfer) \\
\end{tabular}

Source: Greiner and Franza (2003)

The movement of know-how in one technology is different from another type of technology. Each technology goes through different funnels and has different types of consumers. End-users use a food container which is made of plastic processed by particular technology invented in a research institute. Subsequently, researchers working in the lab have not direct link to end users. Ideally, intermediary agency gets the technology of the other side of the process until it reaches the market. The problem occurs when a policy maker sets a legislation in measuring the readiness of technology which puts the outcome of technology in the market.

Technology transfer is one form of innovation diffusion which includes dissemination and communication between related actors including technology providers, government as policy makers and technology users (Kapur, 2001; Phillips, 2002). Moreover, Rogers et al. (2001) define technology transfer links to innovation to view technology which includes social technology as a design for instrumental action that reduces the uncertainty of cause-effect relationship involved in achieving a desired outcome.
It is worth to consider the four following different bases of technology transfer and innovation diffusion (E. M. Rogers, 2002): 1) Technology transfer leads to market and producer Innovation diffusion leads to utilization and technology implementation. Therefore, technology transfer has been widely recognized as technology utilization which not always fits to demand in the market. 2) Technology transfer is part of the organizational structure Innovation diffusion puts its emphasis on analysis and decision of individual and network to diffuse. 3) Technology transfer involves planning and directing Innovation diffusion is more spontaneous. 4) Technology transfer leads to commercialization of research outcome innovation diffusion answer the question of how new technology spread and diffuse.

The process of technology-transfer in most cases appears to have a similar form to innovation diffusion. Lack of literature in technology transfer expands to intellectual property management, prototype development or innovation diffusion. This misconception leads to policy-making process as a number of patent filling function as the indicators for technology transfer achievement. This regime should be treated as the tools to protect intellectual rights, and the makers should be commercially awarded for their contribution. When it is treated as the target, so it consequently rising the number as well as the cost of maintenance. Moreover, 
in public research institute, royalty is not the main objective (Mazzucato, 2014). Government funded research organizations aim to face risk and uncertainty and valuing of financial outcome is in commercial zone. It supported by the example of development of touchscreen with large allocation of government budget.

\section{RESULTS}

\section{Existing Problem}

It is important to set the problem of research in technology transfer to avoid solving the wrong problem. In responding to develop the right problem, the 10 selected expertise respondents were invited to share their opinions through email, informal discussions and discussions over chapter of a book or a journal. The main objective of the first discussion was to set structures of hierarchy in developing AHP. However, this meeting was also open to develop the view of experts of the problems in technology transfer.

The View of Discipline of Technology Innovation Management

Experts have found the awareness of community over the development of science and technology. Problems occurred when they put an unrealistic expectation on ST in narrow-mind while regulator comes with the short-term target and pushes with the concept of market and trade of new technology. Source explained how highest level of government officer expresses his disappointment on ST development: we put IDR27 Trillion for ST development that we still not see good vision on this. It (ST institution) seems that they could produce the research by increasing or decreasing budget. Sometimes we think that they could work without taxpayer money. It is funny to see almost similar research proposal every year. They are good in modification of title, body and budget their old proposal so it looks like new activity. We need the result. The tax-payer have the right to see how their money benefits them. When we see the increasing quantity of import of salt and rice we see the problem in ST development. We imported bioethanol as well, which leads to justifying how the ST contributes to this problem.
Roy Rothwell implied that discussing the issue of innovation technology would lead to nowhere when it was not based on basic concept of innovation to view the market and activities as interdisciplinary field as his popular metaphor of hill climber and valley crosser (Rothwell, 1993). Furthermore, the government should be in the position of widening and strengthening innovation as economic growth through interventionist industrial policies.

Trend in application of research in mass-scale such as military, health service or food security shows that innovation technology is one significant tool. In Bayh- Dole Act, the academicians would work as academic staff or business owners without reducing their remuneration from the government (innovation's golden goose)

Low productivity of patent

A better understanding of inventors on intellectual property has led to the increasing number of patentfilling. However, the achievement is still lower than the number of the overseas patent in Indonesia. Figure 1 is the benchmarking of patent filling in Indonesia.

The source persons explain how a number of successfully-granted patents create expenses when they fail in utilization; we had been conducting socialization of IP to academic staff to give new horizon of in research activities (Bruce, 1999; Gans et al. 2008; Schacht, 2012; Giuri et al. 2013; Hsieh, 2013; Ziegler et al. 2013). We expect they are equipped with ability to understand the market potential of their research while administration officer stimulates the researcher to fill more patent with rewards and incentive. At the end of the day, we deal with creating new expenditure items to renew the patent registration which is a significantly huge amount of budget. So it is more important, for me, to focus on giving more lessons of research utilization than patent management.

The protection of IP that is based on business justification is recommended. Appropriate regime such as patent and trade-secret are treated as the tools of innovation technology and not as the target. 


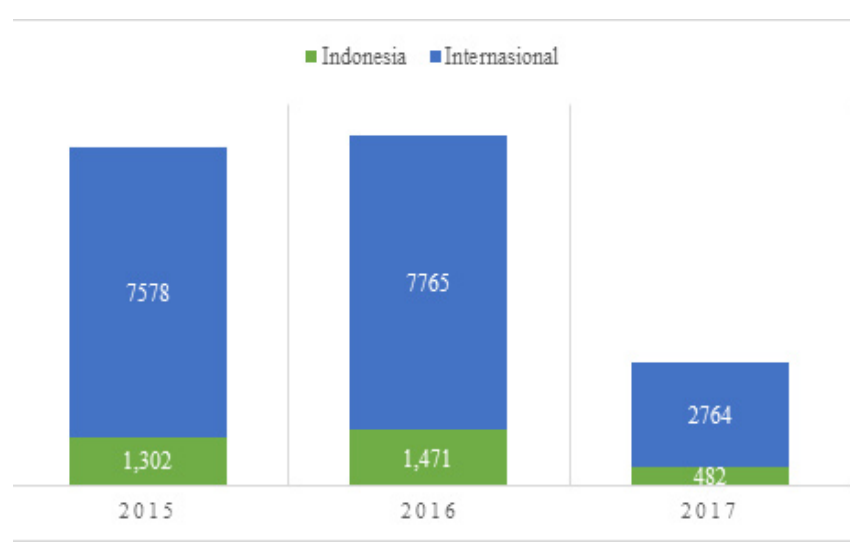

Figure 1. Local and Foreign Patent in Indonesia 2015mid² $^{2}$ (DJHKI, 2017)

\section{Stability of commitment of government}

Priority setting of the government could be indicated by budget allocation. Budget for ST development has been very flexible to dynamics of government expenditure. When the world oil price is rising and we need more capital, so budget for ST development is the easiest post to be accommodated. In contrast, the source explains how the commitment of government-based budget allocated is essential. The accommodation on budget in ST development could influence the performance. It is recommended to have better budget exercise to avoid changes while the process is running.

Putting research and technology as short-term planning

ST development is unique from its root. Research in information, technology and communication takes shorter period from inceptive to application to compare with the period of application in the research of biotechnology, for example. However, it should consider that innovation technology has a potential application in creating new demand or improvement of a product (Etzkowitz et al. 2000; Martin and Etzkowitz, 2000; Yencken and Cantab, 2002; Dodgson, 2006). Similar to the characteristics of application of new technology, innovation technology also offers better solutions in alternative energy (Gallagher et al. 2012) or biotechnology-based products (Dodgson et al. 2008). Problem occurs when each ST development should be set as quick-win which puts -down others potential champions.

Source from one public-research-institute shared cases of how unstable running-budget creates negative impact on ST. Most research projects are conducted through collaborations. The reduction of budget in the running process could damage the relation with potential stakeholders, and it is not easy to maintain the reputation.

\section{Lack of contribution from private sector}

Leidesdorff found three key actors in innovation technology as it is called triple-helix (Leydesdorff, 2000). It consists of Government, Business and Academic. The government sets objective and planning on science technology through budget allocation and issues laws and regulations while universities play as technology providers that have connections with actors of business as technology-users.

The étatisme in technology transfer occurrs when the majority of role is held by the government. Innovation systems of Switzerland, German and United Kingdom (UK) are indicated with dominant roles of the government. Another type of relation is American Centrist where firms have significant roles in ST development. The third type is Laisses Faire where every actor in the system plays the same role and responsibility.

Indonesia as a developing country is also indicated by the dominant role of government and led to better contribution from private sectors. The government provides tax allowance for the firms which have research collaboration with local ST-institutions. Furthermore, techno-entrepreneurship have been encouraged to build a collaboration with researchers in technologybusiness incubators (TBI). Young entrepreneurs entitle access to discuss their problems in production process related to certain technologies. The business coaching and training are also provided by TBI facilitated by the government funding.

\section{Domination of supply driven technology}

The idea of research push is the typical problem in the first stage of technology-based business. It begins with invention where researchers have their idea of particular application. In the other side, researchers in private sectors also conduct similar research h equipped with close relation to the users. The problem occurs when researchers in the firm reject external recommendation of technology . On the other hand, the bridging between technology providers with their users is essential. The metaphor of communication between the white suit 
which represents people working in labs and blue suit as business entity is worth to consider. The white suit is unlikely to do and think like a businessman while the blue suit feel threatened when the researcher plays the role as entrepreneur. It requires the T-Shape people in connecting the system. However, outlier might appear when a researcher successfully creates the business which is based on research.

\section{Building block of technology provider.}

Another problem in developing new application of technology is integrating similar research projects in in public sector. A source person has a positive side and view that similar research projects in public sector as positive critical-mass. A number of projects seem as duplication or have the same objective. However, I guarantee that it has its uniqueness. While most of source persons found the government spending in research activities ineffective, they should be encouraged to communicate their research and conduct their research collaboration.

\section{The Choice of Strategy in Technology Transfer}

The respondents were interviewed separately with a flexible choice of time and location. The selection was based on their expertise in transferring technology as top-level officers with authority to manage and select the technology, managers that conduct selection and commercialization of technology, intellectual property manager, and directors of the association of incubator, and researchers that successfully obtained research to market. The variety of background leads to their expectation of criteria of successful technology transfer project.
Questionnaires had been filled through the interview. The experts had opportunities to explain their choices and opinions. Some of the respondents presented their ideas in PPTs and some shared reports and consultant/ third party proposals on the project in the field of technology transfer. Moreover, the researchers also had chances to explain about AHP and the meaning of the value. The respondents should have a clear information on each question and the researcher were advised to make sure that the answer was consistent with the other answers. If the respondents were left alone and free to answer, it is likely leading to inconsistency.

Transcripts of the questionnaire were entered into the super-decision software with the results in Figure 2. It shows each variable with the weight. The normal weight of variables described in the diagram is derived from AHP by using superdecision software. There are three structures: criteria, actors and alternatives, and the strategic choice in this research is the justification of alternatives in the third structure.

\section{First Structure: Criteria}

Figure 3 shows the level of various criteria on technology transfer process to achieve national competitiveness. The most influential criteria are Patent based on national productivity at 0.348978903 which refer to 34 percent of respondents opinion that successful technology transfer is indicated by the achievement on intellectual property. It is followed by Market Creation at 0.312374265 , Increasing Jobs at 0.193291551, Eco Product at 0.073705964 and Cheaper Cost of Production at the lowest level. The value of each level is viewed on government institutional expert. It tends to be a contrary level from the opinion of the private sector where technological change should be considered as the most efficient of the production process.

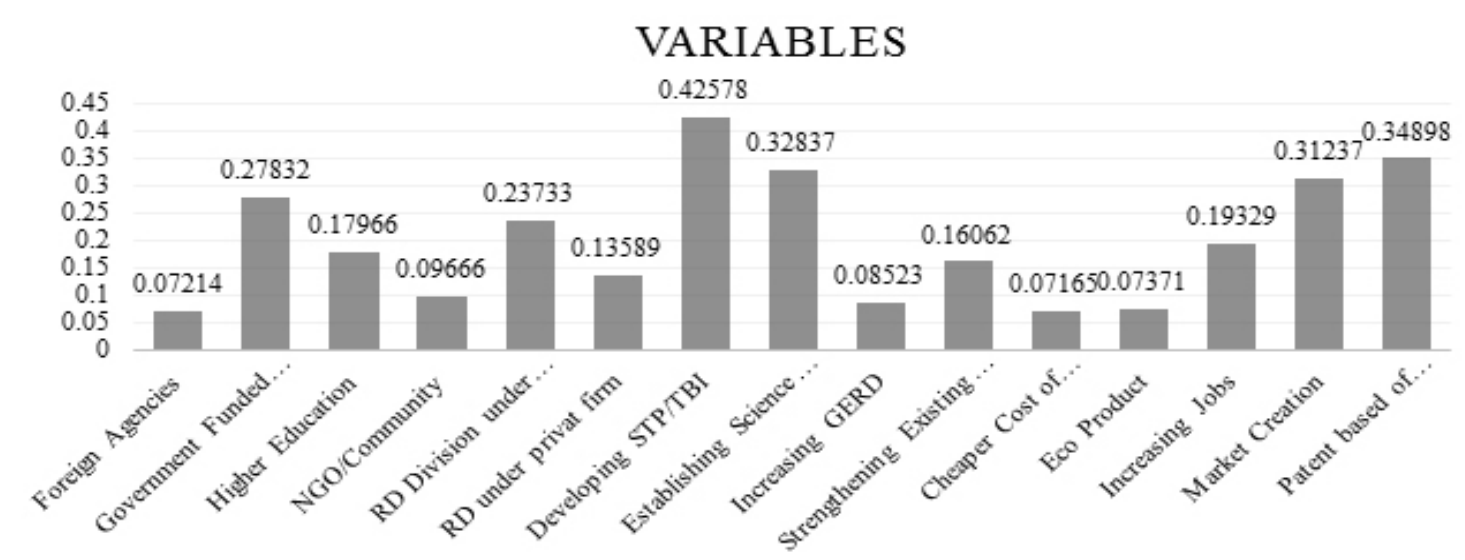

Figure 2. Priority of variables on competitive-based technology transfer 


\section{Criteria}

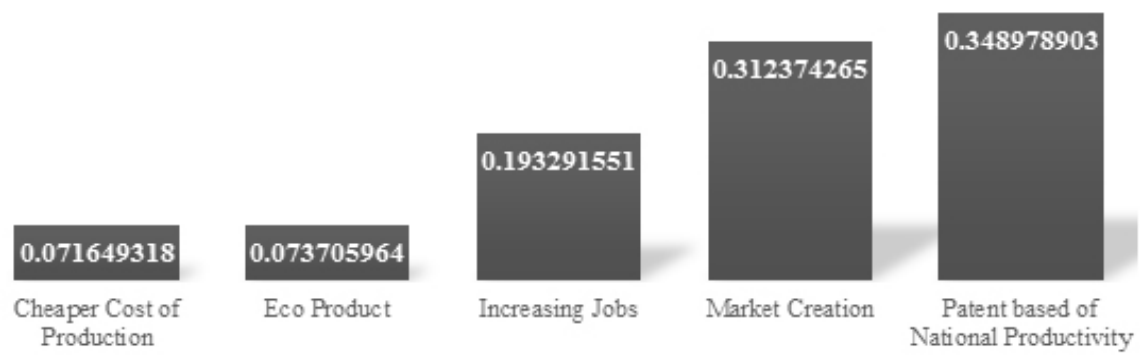

Figure 3. Criteria of technology transfer

The respondents were provided time to explain reasons of their priority and ideal picture of technology transfer. In the interview, the IP Manager described some flaws of regulators and managers to treat the regime appropriately. It should be utilized as protection of intellectual property and not to be treated as the achievement. As a new product that is equipped with novel technology, other parties may easily imitate it. In most cases, that counterfeit created better profits due to low allocation in research and development, and such case is the rationale of right of intellectual property.

However, the cost of maintenance of patent will rise with no return from the market when the appropriate regime is treated as an achievement instead of a tool. It is important to treat market as the mother of successful managing innovation technology. Therefore, new and advanced technology that the creator expects better application for potential users will not always meet sufficient demand in the market. Research on market is essential to equipped commercialization.

Quantity of patent filling from foreign industry in Indonesia has increased, but fewer number of comes from the local patent filling. However, the argument is still relevant not to target the number of patent. Most of patent fillings in Indonesia are related to private sectors whose products are sold in Indonesia. To compete in raising the number of patent filling will not return benefits particularly for the government-funded technology provider.

Productivity of intellectual property is put as a leading criterion. It is important for inventors in gaining benefits from their technology that is successfully available in the market. The problem of blocking research in gaining profit is based on two rationales. First, it is related to the asset that the researcher uses in the research process, and this assets comes from the tax-payers as staff in the government institution receives monthly wages beside other incentives from the government. Equipment and tools are also provided by the government. Based on this reason, it should have a careful consideration in selling the price for the inventions. Second, it is the problem with valuation of products. There are number of methods in valuing the royalty in the patent which leads to either over-pricing or under-value pricing.

The second biggest weight is demand-creation where every new product should start from demand in the market. Market is prerequisite for technological change through an appropriate migration path. The path is not similar from one product to another which is popularly called innovation creates its own arteries. In creating demand on new technology, it is important to have comprehensive understanding in character of target market, product, standard, competitor, and supplier. Therefore, creating demand should rely more on the ability of marketing the product than making the product. The best technology in a product does not guarantee its successfulness in the market.

Based on the discussion, green products have less attention than efficient technology. If the green products could go with cheap price, people will be happy to buy them. The awareness of environment-friendly products is still low in developing countries. As the third criteria, green products have the third weight as the vision of experts to fulfill the basic needs through technological change. It has a close connection with efficient production process in the fourth criteria. Most of respondents mentioned the imported cheap products from China. It is not our position to go head-to-head with products from China. What we expect from innovation technology is that the ability in providing better products that root from our own core value. 
Young generation in Bandung (Capital City of West Java) remarkably produces the software program. It is such a success story. Therefore, it should include better justification to produce national-transportation which will compete with car manufacturers from Japan.

\section{Second Structure: Actors}

The RD Division under Ministerial Office plays the major role in strengthening the capability of technology transfer system at 0.24890 , which is followed by Government Funded Research Institutions at 0.21343, Higher Education at 0.19519, Non-GovernmentOrganization/Community at $0.12290, \mathrm{RD}$ under private firm at 0.11801 and Foreign Agency at 0.10158 (Figure 4).

Research and development under technical ministries play a significant role in technology transfer. This division works to provide services to the ministry as most of the products have niche market. The tight connection between the researchers and users leads to a better flow of technology transfer to compare to other actors that need to define their demand. One of respondents gave a presentation on the model of technology transfer in a number of well-known universities in Indonesia. He showed that many bodies in the universities provide similar services as mediators of new technology. However, that slides also showed a public-research-institute that conducts a one-man-show where all the functions of inter-mediator, accelerator, STP and BTI are in one division. Both cases show ambiguous objectives which differentiate RD division of ministries, but public-research-institutes and universities are in the second and third position.

The fourth actors are NGO and communities that have a significant role in rural area. Creation of new application in agriculture could be effective when it involves a prominent figure of the community. In Bali, for example, the informal-culture-leader is awarded more significant authority than the chief of leader although they are not in the position of technology provider, their role is vital in transferring new technology.

The fifth variable of actors is RD division in industry. The role of this division is similar to RD division under technical ministries that they conduct research as it is offered by the ministry. RD division solves the product manufacturing process or marketing. However, this division has a tight connection with the principal and most of manufacturer of MNC established RD-division outside the country. Researchers from local institutions should communicate to the principal to engage in collaboration.

The sixth actor is foreign agencies that consist of representatives of foreign governments, universities or industries. The connection with their counterparts in Indonesia is usually based on individual or institution relation. It is easier to conduct a collaboration in research than in business. A number of joint researches have successfully published their journal articles and reports. Furthermore, the first problem occurred when it dealt with ownership of research.

\section{Actors}

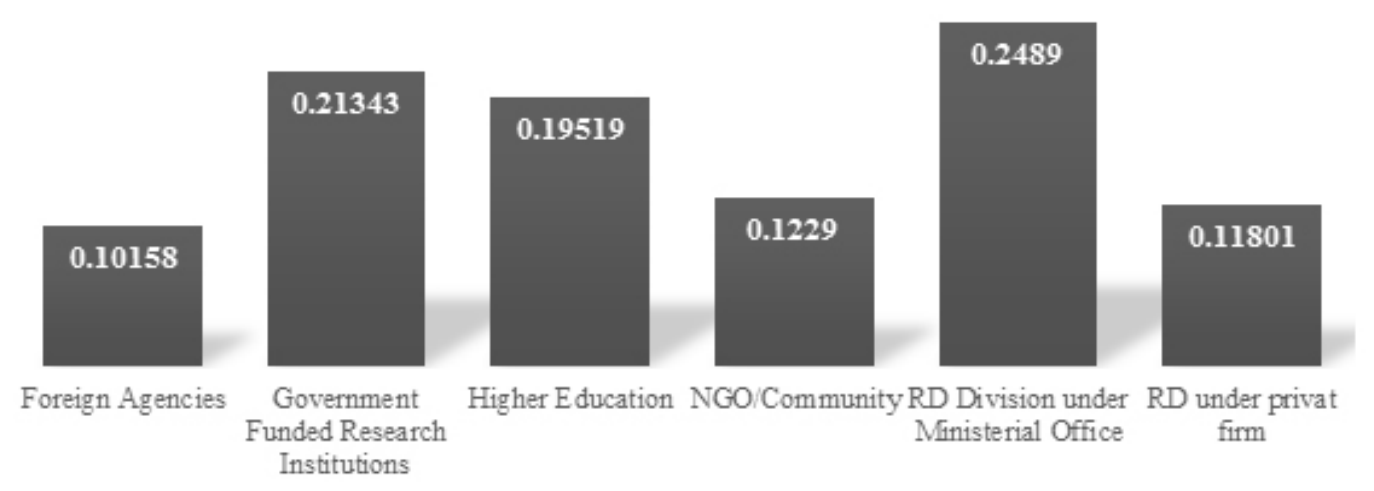

Figure 4. Actors in technology transfer 


\section{Third Structure: Alternatives}

Alternative strategy is in the third structure which consists of possible policy that could be taken by the government in strengthening competitiveness-based technology transfer. The highest weight is establishment of science-technology park (STP) and technologybusiness incubator (TBI) of 0.50414 and followed by development of ST-representatives of 0.24344 , restore of existing research institutions of 0.16648 and increase in RD gross expenditure of 0.08594 (Figure 5).

The creation of young entrepreneurship is essential in Indonesia that it is less than $0.50 \%$ of total population. It is less than the proportion of entrepreneurs in Malaysia of more than $5 \%$ or Thailand of $7 \%$. One main function of TBI is to create new entrepreneurs by providing access to researchers and research facility, business coaching, and IP clinic and training on entrepreneurship. On the other hand, industry is also benefited from the establishment of STP where most of advance and ready-to-run technologies are provided. All respondents agreed that the achievements of both STP and TBI are essential in economic growth. The priority of regional development is attached to the theme of STP, so this body is engaged closely to industry and regional administrative office. In conjunction to these primary roles, it is advised to involve university and regional research bodies.
The second choice is the establishment of ST representatives popularly called ST Attaché. This choice is recommended to address borderless-world and sustainable-development-goals. It is a philosophical view on science as one of the universal domains, so the representatives of ST are a requirement. Albeit, the short vision of regulator on ST is likely to apply the quick-win to this idea. The respondents agreed on the position of the extensiveness of biodiversity that attracts foreign researchers and institutions to join the collaboration which leads to instituting a flagship project. However, most of flagship vanish when the individual researcher is retired.

To address quick-win vision on developing ST-Attaché, big firms are recommended as representatives. Therefore, it is not a direct use of the government budget. Experts augmented this idea with a better communication between research institutes, industries and foreign-agencies, so the limited government fund would be more expedient in aiming two objectives.

Restoration of existing research institute is the third recommendation as the constellation of organization and legislation has already been sufficient. Creating another body will be insufficient that leads to immoderate of government expenditure . The ongoing development of research institution is addressed in enhancing the capabilities of utilization of research and human resource development. It is also influenced by Industrial 4.0 scheme that is adopted in Industrial Research and Development Agency (BPPI) .

\section{Alternatives}

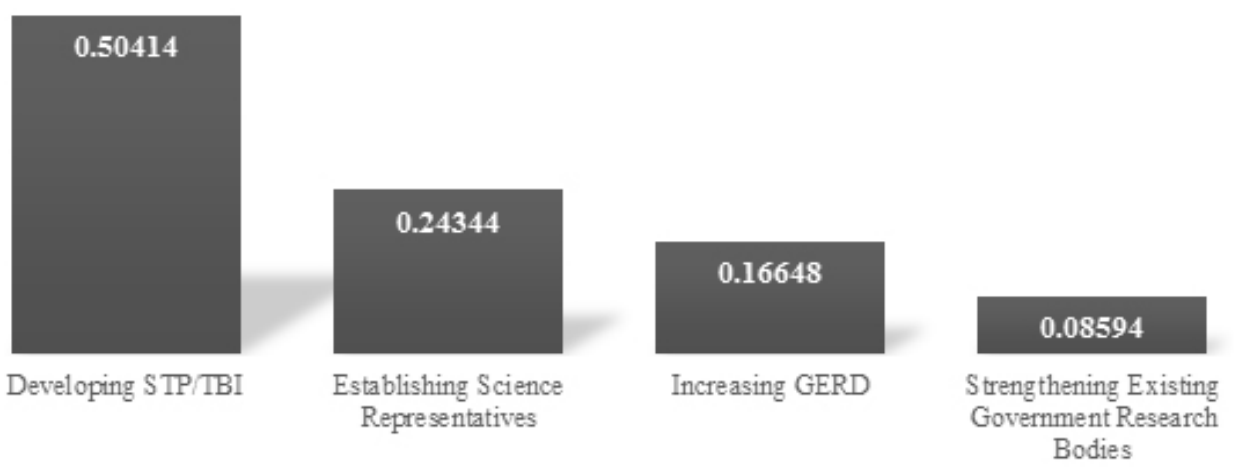

Figure 5. Strategic choice on technology transfer 
Increasing gross expenditure on research and development (GERD) is the spare strategy that most of experts found unnecessary. If we set the unlimited funding for research and development, I wonder what they will make and what they will offer to this nation to consider that they could work when we accept their proposal or when we decrease their budget. Moreover, we do not see a significant research in addressing national call. However, it should consider the position of the government funding research organization in creating disruptive-innovation where the not-forprofit research entities invent the world-class research. From nuclear reactor to transistor and from touchscreen to Wi-Fi are recognized as the production of the government research institute, and it should not be set up as the commercial entity.

\section{Managerial Implication}

In this study, we offer three policy recommendations of strategic choices. The combination among the four strategies in establishing TBI and STP; developing ST representatives, restoring the existing research organizations and increasing gross expenditure on research and development.

The next managerial implication is developing national curriculum of technology transfer (Ministry of Research Technology and Higher Education; Ministry of Cooperative and SME, Ministry of Industry, Ministry of Agriculture, Universities, Indonesian Ministry of National Development Planning and related NGO). Building the form of qualification and prerequisite for technology transfer (Ministry of Research Technology and Higher Education, Ministry for Economic Coordinator, Indonesian Ministry of National Development Planning. Establishing science and technology attaché in strengthening National Competitiveness Based Technology Transfer (Ministry of Research Technology and Higher Education; Ministry of Foreign Affairs, Ministry of Finance)

\section{CONCLUSIONS AND RECOMMENDATIONS}

\section{Conclusions}

The reseach findings have a significant outcome to technology transfer and strategic management literature. Bridging from research to utilization is the most complicated process where the inter-mediators and accelerators should be equipped with outstanding communication skills. Moreover, the research in innovation study as interdisciplinary in this study integrates theory in the field of strategic management and technology innovation management.

\section{Recommendations}

As Rothwell believes that innovation study is interdisciplinary field as such valley crosser and hill climber, the research is recommended to explore in macro and micro scales. Further research on micro-scale that intensively explores one particular organization is advised.

\section{ACKNOWLEDGMENT}

This paper has been developed by the first author in his Doctoral dissertation funded by Ministry of Research Education and Higher Education of the Republic of Indonesia decree number 35/M/Kp/IX/2014.

\section{REFERENCES}

Adner R, Rahul K. 2010. Value creation in innovation ecosystems: how the structure of technological interdependence affects firm performance in new technology generations. Strategic Management Journal 31(3): 306-333. https://doi.org/10.1002/ smj.824.

Aghion P, Paul AD, Dominique F. 2009. Science, technology and innovation for economic growth: Linking policy research and practice in 'STIG Systems'. Research Policy 38(4): 681-93. https://doi.org/10.1016/j.respol.2009.01.016.

Agrawal A, Iain C, Carlos R. 2010. Not invented here? innovation in company towns. Working Paper 15437. https://doi.org/10.3386/w15437.

Aiman S, Hakim L, Simamora M. 2004. National Innovation System of Indonesia: A Journey and Challenges. Bogor: [LIPI] Lembaga Ilmu Pengetahuan Indonesia.

Bruce CD. 1999. Commercialization of academic research (Patent, publish and flourish). Theriogenology 51(1):3. https://doi.org/10.1016/ S0093-691X(98)00248-9.

Burcharth ALDA, Mette PK, Helle AS. 2014. Neither invented nor shared here: The impact and management of attitudes for the adoption 
of open innovation practices. Technovation 34(3):149-161.https://doi.org/10.1016/j. technovation.2013.11.007.

Davies R. 2015. Industry 4.0. Digitalisation for productivityand growth.European Parliamentary (Briefing) September 2015: 1-10.

[DJHKI] Direktorat Jenderal Hak Kekayaan Intelektual Republik Indonesia. 2017. Pendaftaran Paten Lokal Dan Internasional Di Indonesia 20152017.http://statistik.dgip.go.id/statistik/ production/paten_negara.php.

Dodgson M. 2006. Developing business from scienceinstitutions of science and intermediaries. Fortune.

Dodgson M, John M, Tim K, Mei CH. 2008. The evolving nature of Taiwan's national innovation system: The case of biotechnology innovation networks. Research Policy 37(3): 430-445. https://doi.org/10.1016/j.respol.2007.12.005

Etzkowitz H, AndrewW, Christiane G, Branca RCT. 2000. The future of the university and the university of the future: evolution of ivory tower to entrepreneurial paradigm. Research Policy 29(2): 313-330.

Fiaschi D, Rodolfo S. 2003. Consumption patterns, development and growth: Adam Smith, David Ricardo and Thomas Robert Malthus. European Journal of the History of Economic Thought 10(1): 5-24. https://doi.org/10.1080/096725603 2000043779.

Gallagher KS, Arnulf G,Laura K, Gregory N, Charlie W. 2012. The energy technology innovation system. Annual Review of Environment and Resources 37(1): 137-62.

Gambardella A, McGahan AM. 2010. Business-model innovation: general purpose technologies and their implications for industry structure. Long Range Planning 43(2-3): 262-271.

Gans JS, Hsu DH, Stern S. 2008. The impact of uncertain intellectual property rights on the market for ideas: evidence from patent grant delays. Management Science 54(5): 982-997. https://doi.org/10.1287/mnsc.1070.0814

Giuri P, Munari F, Pasquini M. 2013. What determines university patent commercialization? empirical evidence on the role of IPR ownership. Industry and Innovation 20(5): 488-502. https://doi.org/1 $0.1080 / 13662716.2013 .824195$

Greiner M, Franza RM. 2003. Barriers and bridges for successful environmental technology transfer. Journal of Technology Transfer 28: 167-77.
https://doi.org/10.1023/A:1022998617118.

Grosse KD, Leker J. 2012. Knowledge transfer in academia: an exploratory study on the NotInvented-Here Syndrome. The Journal of Technology Transfer 37(5): 658-675.

Hasheminejad M, Meisam T, Yaghoub M, Mahdi K, Azita J. 2011. Upstream and downstream strategies to economize biodiesel production. Bioresource Technology 102(2): 461-468. https://doi.org/10.1016/j.biortech.2010.09.094.

Henning, Kagermann. 2013. Recommendations for Implementing the Strategic Initiative INDUSTRIE 4.0. Final report of the Industrie 4.0 WG.

Hsieh CH. 2013. Patent value assessment and commercialization strategy. Technological Forecasting and Social Change 80(2): 307-319. https://doi.org/10.1016/j.techfore.2012.09.014

Kapur D. 2001. Diasporas and technology transfer. Journal of Human Development 2(2): 265-286. https://doi.org/Article

[Kemenristekdikti]Kementerian Riset Teknologi dan Pendidikan Tinggi. 2017. Inisiasi Regulasi Penguatan Technology Transfer Office. Jakarta: Kemenristekdikti.

Leydesdorff L. 2000. The triple helix: an evolutionary model of innovations. Research Policy 29(2): 243-55.https://doi.org/10.1016/S00487333(99)00063-3.

Maludin S 2009. Strategi Pengembangan Produk Inovasi. Jakarta: LIPI.

Martin BR, Etzkowitz H. 2000. The origin and evolution of the university species. Journal for Science and Technology Studies 13(3): 9-34.

Mazzucato M. 2014. A mission-oriented Approach to Building the Entrepreneurial State. Anthem Press.

Mubarok R. 2007. Alih teknologi melalui perjanjian lisensi kaitannya dengan undang-undang nomor 14 tahun 2001 tentang paten. Hukum dan Masyarakat 5(0854): 1-10.

[OECD] Organisation for Economic Cooperation and Development. 2007. OECD Principles and Guidelines for Access to Research Data from Public Funding. Paris: OECD Publishing

Pfeiffer S. 2017. The vision of "industrie 4.0 " in the making a case of future told, tamed, and traded. NanoEthics 11(1): 107-121. https://doi. org/10.1007/s11569-016-0280-3.

Phillips RG. 2002. Technology business incubators: how effective as technology transfer mechanisms? 
Technology in Society 24(3): 299-316. https:// doi.org/10.1016/S0160-791X(02)00010-6.

Reisman A. 2005. Transfer of technologies: A crossdisciplinary taxonomy. Omega 33(3): 189-202. https://doi.org/10.1016/j.omega.2004.04.004

Ringle CM, Sarstedt M, Mooi E. 2010. Responsebased segmentation using finite mixture partial least squares: theoretical foundations and an application to american customer satisfaction index data. Annals of Information Systems 8:1949.https://doi.org/10.1007/978-1-4419-1280$0 \_2$.

Roessner JD, Wise A. 1994. Public policy and emerging sources of technology and technical information available to industry. Policy Studies Journal 22(2): 349-58. https://doi.org/10.1111/j.15410072.1994.tb01473.x.

Rogers EM. 2002. The nature of technology transfer. Science Communication 23(3): 323-41. https:// doi.org/10.1177/107554700202300307.

Rogers EM, Shiro T, Jing Y. 2001. Lessons learned about technology transfer. Technovation 21(4): 253-61. https://doi.org/10.1016/S01664972(00)00039-0.

Rosenberg N. 1974. Science, invention and economic growth. The Economic Journal 84(333)90-108, https://doi.org/10.2307/2230485.

Roth AE, Tayfun S, Ünver MU. 2005. A Kidney Exchange Clearinghouse in New England. American Economic Review 95(2): 376-80.

Rothaermel FT. 2015. Strategic Management. New York: McGraw Hill.

Rothwell R. 1993. The changing nature of the innovation process. Technovation 13(1): 1-2. https://doi. org/10.1016/0166-4972(93)90009-K.

Saaty TL. 2003. The analytic hierarchy process (AHP) for decision making and the analytic network process (ANP) for decision making with dependence and feedback. Creative Decisions
Foundation 114.

Santos C, Mehrsai A, Barros AC, Araújo M, Ares E. 2017. Towards Industry 4.0: an overview of European strategic roadmaps. Procedia Manufacturing 13: 972-979. https://doi. org/10.1016/j.promfg.2017.09.093.

Schacht WH. 2012. The Bayh-Dole Act: Selected issues in patent policy and the commercialization of technology. CRS Report.

Shen YC, Shu HC, Grace TRL, Hsiao CY. 2010. A hybrid selection model for emerging technology. Technological Forecasting and Social Change 77(1): 151-66. https://doi.org/10.1016/j. techfore.2009.05.001.

Simamora M, Syahrul A, Kurleni U, Syafrizal M. 2005. Regional innovation system and sustainable competitiveness: case study on food processing SMEs in West Java and Lampung Provinces. Available at SSRN: https://ssrn.com/ abstract $=2728688$ or http://dx.doi.org/10.2139/ ssrn. 2728688

Sugiyono, Rachma NN, Manaek S. 2008. Science and Technology Network in the innovation system of up-stream palm oil industry in Indonesia.SSRNid 2729226

Sulastri E. 2014. Analisis kewajiban alih teknologi dalam investasi asing di Indonesia. Jurnal Sosial dan Budaya Syar-i 1(2): 267-280. doi:https:// doi.org/10.15408/sjsbs.v1i2.1545

Yencken J, Cantab MA. 2002. Commercialising Research through Spin-off Companies. UK: European IPR Helpdesk.

Ziegler N, Frauke R, Martin AB, Oliver G. 2013. Creating value through external intellectual property commercialization: a desorptive capacity view. Journal of Technology Transfer 38(6): 930-49. https://doi.org/10.1007/s10961013-9305-z. 